\title{
Fiscal Policy and Stock Market Development in
} an Emerging West African Economy: The Case of Nigeria

\section{Dr Paschal Chikwado Nwakobi ${ }^{1}$, Amalachukwu Chijindu Ananwude ${ }^{2 *} \&$ Chinedu Maurice Umezurike ${ }^{3}$}

\author{
${ }^{1}$ Department of Banking and Finance, Enugu State University of Science and Technology, Enugu State, PMB 01660, \\ Enugu, Nigeria \\ ${ }^{2}$ Department of Banking and Finance, Nnamdi Azikiwe University, Anambra State, PMB 5025, Awka, Nigeria \\ ${ }^{3}$ Department of Banking and Finance, The Federal Polytechnic, P. B. M. 1012, Kaura Namoda, Zamfara State, Nigeria \\ *Corresponding author: amalision4ltd@yahoo.com
}

Doi: $\underline{\text { https://doi.org/10.38157/finance-economics-review.v2i3.182 }}$

Citation: Nwakobi, P. C., Ananwude, A. C., \& Umezurike, C. M. (2020). Fiscal Policy and Stock Market Development in an Emerging West African Economy: The Case of Nigeria, Finance \& Economics Review, 2(3), 52-68. Doi: https://doi.org/10.38157/finance-economics-review.v2i3.182

\section{Research Article}

\section{Abstract}

Purpose: This article presents a study on the effect of fiscal policy on stock market development in an emerging West African economy with an emphasis on Nigeria for the period of 1986 to 2018. Specifically, we evaluated the effect of fiscal deficit on all share index including government total expenditure on market capitalization ratio, the value of stock traded, and turnover ratio using data from the Central Bank of Nigeria (CBN) and Nigerian Stock Exchange (NSE).

Methods: The Auto-regressive Distributive Lag (ARDL) was the estimation technique employed in ascertaining the nature of the short-run relationship between fiscal policy and stock market development indices, whereas the effect of fiscal policy on stock market development was actualized under the granger causality analysis.

Results: The result of the analysis revealed that fiscal deficit has no significant effect on all share index; government total expenditure has no significant effect on stock market capitalization ratio; government total expenditure has a significant effect on the value of stock traded ratio; government total expenditure has no significant effect on the stock market turnover ratio.

Implication: Government should implement its fiscal policies to carefully accommodate the development of the stock market, as changes in fiscal policy affect the overall activities in the market and ultimately the economy.

Keywords: Fiscal Deficit; Government Revenue; All Share Index; Market Capitalization Ratio, Value of Stock Traded Ratio; Turnover Ratio. 


\section{Introduction}

The financial system plays a critical role in the economic growth and development of any country, especially emerging economies. Stock markets are one of the relevant constituents of the financial system, which help firms or companies to raise capital by issuing their shares and also create an enabling environment which allows for trading of the shares (Okonkwo, Ananwude \& Echekoba, 2015). A fiscal stun due to tax shifting or in spending by the government will, at a few points in time, compel long-standing time path of taxes and spending, since the government's inter-temporal budget imperative will in the long run have to be met (Favero \& Giavazzi, 2007). Fiscal deficit as a fiscal policy tool is considered to be counterproductive as it has the potential to stimulate a rise in interest rates which in turn, inhibit investment by the private sector as the government also competes for available resources to finance the deficit, while private consumption would be significantly reduced. In such circumstances, the crowding out of the private investments by the government can outweigh any short-term benefits associated with such expansion in government spending (Akanni \& Osinowo, 2013). Fiscal deficit will result in the government acquiring more debt and introducing high tax rates to cover the interest costs of debt. From the neoclassical hinge point, these high-interest rates and taxes accompanying fiscal deficit would equipoise the benefits associated with the fiscal deficit. Justification of fiscal deficit as an ideal fiscal policy tool during a period of economic recession (as the government will borrow at low-interest rate) is still not worth it because, during the economic recovery process, there will be in one way or the other, an amalgamation of higher interest rates and taxes to assiduously finance and re-finance the debt.

The effects of the fiscal deficit can also depend on the type of the sectors the government decides to spend on. For illustration, a fiscal deficit can have positive macroeconomic impacts in the long-run if it is utilized to fund additional capital investment that leads to an increment within the stock of national resources. Expanded investment on the transport and basic infrastructure (roads, telecommunication, power supply, etc.) makes strides the supply-side capacity of the economy advancing long-run development; for illustration, expanded government venture in education and wellbeing of her citizens can bring positive impacts on work efficiency, employment, and business. That notwithstanding, wasteful spending such as excessive government expenditure on official travels and conferences has proven not to contribute to economic growth and development. Revenue from taxation is another instrument of fiscal policy that affects the development of the stock market. If the government revenue outweights its expenditure there would be surplus that would be channeled to infrastructure that will stimulate industrial performance, hence improving the financial performance of firms in the stock exchange and encouraging more listing on the exchange. However, in the scenario where the expenditure is higher than revenue, the government would resort to increasing tax or borrowing (domestic or external) to argument the shortfall. Persistent or increased external borrowing could give way for fiscal deficit to strive which economists argue that it crowds out private investments in emerging economies. 
Studies on fiscal policy and stock market performance as well as stock market returns have been undertaken by various researchers in Nigeria (see Prukumpai \& Sethapramote, 2019; Nwaogwugwu, 2018; Eyo, 2018; Perveen \& Rahman, 2018; Onyema, 2017; Kuncoro, 2017; Anghelache, Jakova \& Oanea, 2016; Ogbulu, Torbira \& Umezinwa, 2015; Ali, Zaman Ziaei \& Anuar, 2014; Mutulis \& Olweny, 2018; Gowriah, Seetanah, John \& Keshav, 2014; Cheng \& Sun, 2013; Hsing, 2013; Bekhet \& Othman, 2012; Osamwonyi \& Evbayiro-Osagie, 2012). However, about stock market development using the World Bank (2013) indices of measuring development in the stock market (stock market capitalization ratio, the value of stock traded ratio, and turnover ratio) have often been ignored in studies conducted in Nigeria. This creates a lacuna that needs to be filled in this subject area, and it is against this backdrop that this study seeks to evaluate the effect of government fiscal policy on the stock market development of an emerging economy in West Africa: Nigeria.

Having introduced the background to this study in section one (introduction), the other parts of this study are arranged as follows: section two reviews relevant literature on the subject matter, section three details the methodology adopted by this study, section four discusses the findings from the analysis; whereas conclusion and policy implication was detailed in section five.

\section{Literature Review}

Fiscal policy to a layman language deals with the instruments the government uses to influence aggregate demand and supply in the economy to ensure sustainability in economic growth and development. The three foremost apparatus of fiscal policy in Nigeria are government expenditure/consumption, taxation/revenue, and fiscal deficit/borrowing. The stock market supports the platforms for which firms can raise long term capital. Economies with the elegant or functioning industrial sectors (e.g. USA, China, Japan, etc.) are often associated with developed stock markets.

Although theories most significantly, Modern Portfolio Theory, Fiscal Theory and Efficient Market Hypothesis have been propounded to relate government policies to stock market development, however we limited our discussion briefly to the Efficient Market Hypothesis and the Fiscal Policy Theory. The Efficient Market Hypothesis envisages that current prices of stocks on the stock exchange reflect available information about the firm as well as that of government through various policies, for instance, change in the monetary policy rate and fixing of the exchange rate. The Efficient Market Hypothesis is built in three forms: weak, semi-strong, and strong form efficiency. The weak form efficiency of the stock market connotes a situation where current prices of stocks are a reflection of past information relating to stock prices. The semistrong form entails that the current prices of stocks are a mirror image of publicly available information. The strong form efficiency explains the scenario where past information (private and public) fully depict in current prices of the stock on the exchange. The fiscal policy theory assumes that fiscal discipline (maintaining a balanced or surplus budget) by the government is required to sustain stability in the price level in the economic cycle. The theory argues that where the government fails to maintain fiscal discipline, it would resort to a fiscal deficit which may result in inflationary tendency in the future thus, distortion in the price level. The fiscal 
policy hypothesis is against the conventional economic theory that the level of money supply in the economy in the long-run determines the price level.

We have pointed out earlier that studies relating fiscal policy with stock market development in Nigeria have been often ignored by previous researchers hence, we present just few a studies on government policies and stock market returns, and performance in a tabular form in Table 1.

Table 1: Summary of Empirical Studies Reviewed

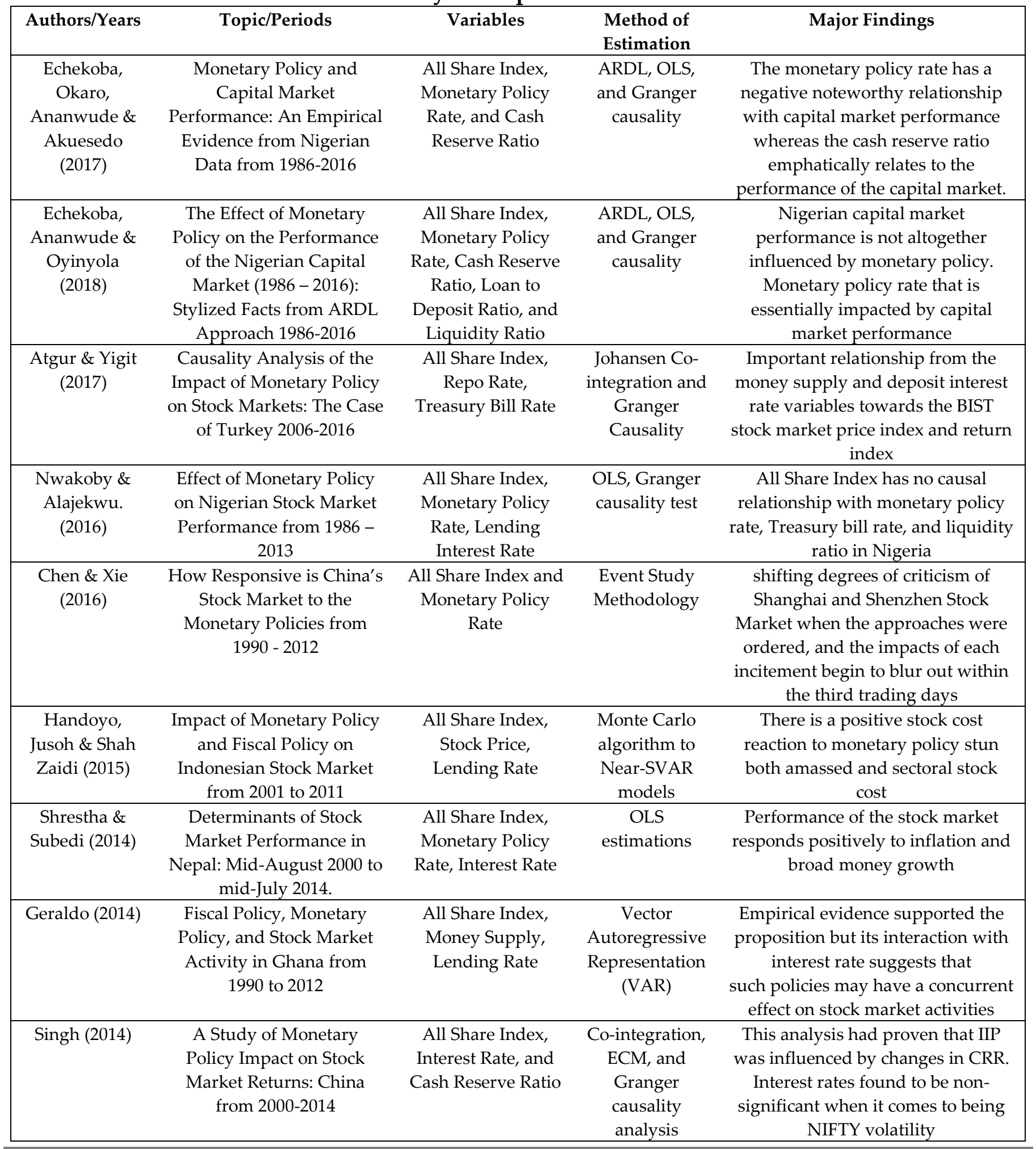


Finance \& Economics Review 2(3), 2020

\begin{tabular}{|c|c|c|c|c|}
\hline Afroze (2013) & $\begin{array}{l}\text { Impact of Monetary Policy } \\
\text { of Bangladesh Bank on the } \\
\text { Performance of Stock } \\
\text { Market in Bangladesh from } \\
\quad 2006-2010\end{array}$ & $\begin{array}{l}\text { All Share Index, } \\
\text { Money Supply, } \\
\text { Repo Rate }\end{array}$ & $\begin{array}{c}\text { Pearson } \\
\text { Correlation }\end{array}$ & $\begin{array}{c}\text { There was a statistically significant } \\
\text { correlation amongst the indicators } \\
\text { for measuring money supply and } \\
\text { the indicators for measuring the } \\
\text { performance of Dhaka Stock } \\
\text { Exchange Limited }\end{array}$ \\
\hline Hsing (2013) & $\begin{array}{l}\text { Effects of Fiscal Policy and } \\
\text { Monetary Policy on the } \\
\text { Stock Market in Poland } \\
\text { 1999.Q2 to 2012.Q4 }\end{array}$ & $\begin{array}{l}\text { All Share Index, } \\
\text { Money Supply, and } \\
\text { Interest Rate }\end{array}$ & GARCH model & $\begin{array}{l}\text { Index of Poland's stock market is } \\
\text { emphatically related to industrial } \\
\text { production and stock market } \\
\text { performance in Germany and the } \\
\text { U.S. are adversely influenced by the } \\
\text { ostensible compelling exchange rate } \\
\text { and inflation rate }\end{array}$ \\
\hline $\begin{array}{l}\text { Muktadir-Al- } \\
\text { Mukit (2013) }\end{array}$ & $\begin{array}{l}\text { An Econometric Analysis } \\
\text { of the Impact of Monetary } \\
\text { Policy on Stock Market } \\
\text { Performance in Bangladesh } \\
2006 \text { to } 2012 \\
\end{array}$ & $\begin{array}{l}\text { All Share Index, } \\
\text { Repo Rate, } \\
\text { Treasury Bill Rate, } \\
\text { Money Supply }\end{array}$ & $\begin{array}{l}\text { Co-integration, } \\
\text { ECM, and } \\
\text { Granger } \\
\text { causality } \\
\text { analysis } \\
\end{array}$ & $\begin{array}{c}\text { Granger causality analysis suggests } \\
\text { the existence of unidirectional } \\
\text { causality from inflation, money } \\
\text { supply, and T-bill to market } \\
\text { index }\end{array}$ \\
\hline $\begin{array}{c}\text { Nemaorani } \\
\text { (2012) }\end{array}$ & $\begin{array}{l}\text { Impact of monetary policy } \\
\text { on stock prices: Evidence } \\
\text { from Botswana from } 2001 \\
\text { to } 2011 \\
\end{array}$ & $\begin{array}{l}\text { All Share Index, } \\
\text { Monetary Policy } \\
\text { Rate }\end{array}$ & $\begin{array}{c}\text { Granger } \\
\text { Causality, and } \\
\text { VAR }\end{array}$ & $\begin{array}{l}\text { The empirical results of this study } \\
\text { suggest that shifts in monetary } \\
\text { policy indeed leads to a change in } \\
\text { stock returns }\end{array}$ \\
\hline $\begin{array}{c}\text { Wang \& Mayes } \\
\text { (2012) }\end{array}$ & $\begin{array}{c}\text { Monetary policy } \\
\text { announcements and stock } \\
\text { reactions: An international } \\
\text { comparison. Zealand, } \\
\text { Australia, the United } \\
\text { Kingdom, and the Euro } \\
\text { area }\end{array}$ & $\begin{array}{l}\text { All Share Index, } \\
\text { Inflation, Money } \\
\text { Supply }\end{array}$ & $\begin{array}{c}\text { Event-study } \\
\text { Methods }\end{array}$ & $\begin{array}{l}\text { New Zealand and Australian stock } \\
\text { markets display significant } \\
\text { reactions to policy rate changes }\end{array}$ \\
\hline $\begin{array}{l}\text { Muktadir Al } \\
\text { Mukit \& } \\
\text { Shafiullah } \\
\text { (2012) }\end{array}$ & $\begin{array}{l}\text { Impact of Monetary Policy } \\
\text { on Post Crashed Stock } \\
\text { Market Performance: } \\
\text { Evidence from Dhaka Stock } \\
\text { Exchange } \\
\end{array}$ & $\begin{array}{l}\text { All Share Index, } \\
\text { Money Supply, } \\
\text { Repo Rate, and } \\
\text { Inflation }\end{array}$ & $\begin{array}{l}\text { Cointegration } \\
\text { technique, and } \\
\text { Granger } \\
\text { causality test }\end{array}$ & $\begin{array}{l}\text { Unidirectional causality from } \\
\text { inflation to DGEN index and money } \\
\text { supply to DGEN index }\end{array}$ \\
\hline $\begin{array}{l}\text { Mohamadpour, } \\
\text { Behravan, } \\
\text { Espahbodi \& } \\
\text { Karimi (2012) }\end{array}$ & $\begin{array}{l}\text { An Empirical Study of } \\
\text { Relationship between } \\
\text { Monetary Policy and Stock } \\
\text { Market Performance in } \\
\text { Malaysia from } 1991 \text { to the } \\
\text { first quarter of } 2011\end{array}$ & $\begin{array}{l}\text { All Share Index, } \\
\text { Money Supply, and } \\
\text { Interest Rate }\end{array}$ & $\begin{array}{l}\text { Co-integration } \\
\text { analysis and } \\
\text { Vector Error } \\
\text { Correction } \\
\text { Models } \\
\text { (VECM) }\end{array}$ & $\begin{array}{l}\text { Factually noteworthy relationship } \\
\text { between M1 and M2 as a money } \\
\text { related supply variable included } \\
\text { within the estimation; so that M1 } \\
\text { and M2 has a long term impact on } \\
\text { the Kuala Lumpur Composite index }\end{array}$ \\
\hline $\begin{array}{l}\text { Iglesias \& } \\
\text { Haughton } \\
\quad(2011)\end{array}$ & $\begin{array}{c}\text { Interaction between } \\
\text { Monetary policy and stock } \\
\text { prices: A comparison } \\
\text { between the Caribbean and } \\
\text { the US, Barbados, Jamaica, } \\
\text { and Trinidad and Tobago }\end{array}$ & $\begin{array}{l}\text { All Share Index, } \\
\text { Treasury Bill Rate, } \\
\text { Lending Rate }\end{array}$ & $\begin{array}{l}\text { Structural } \\
\text { VAR: Granger, } \\
\text { Variance } \\
\text { Decomposition } \\
\text { \& Impulse } \\
\text { Response } \\
\text { Function } \\
\end{array}$ & $\begin{array}{l}\text { The effect of a monetary policy } \\
\text { shock is greater in the US; while the } \\
\text { effect of a stock price shock is } \\
\text { smaller in the US than in the } \\
\text { Caribbean }\end{array}$ \\
\hline $\begin{array}{l}\text { Qayyum \& } \\
\text { Anwar (2011) }\end{array}$ & $\begin{array}{l}\text { Impact of Monetary Policy } \\
\text { on the Volatility of the } \\
\text { Stock Market in Pakistan } \\
\text { from 1st July } 1998 \text { to } 27 \\
\text { May } 2008\end{array}$ & $\begin{array}{l}\text { All Share Index, } \\
\text { Monetary Policy } \\
\text { Rate }\end{array}$ & $\begin{array}{l}\text { ARCH- } \\
\text { GARCH }\end{array}$ & $\begin{array}{l}\text { Any change in the monetary policy } \\
\text { stance has a significant impact on } \\
\text { the volatility of the stock market }\end{array}$ \\
\hline
\end{tabular}


(C) Nwakobi, Ananwude \& Umezurike

\begin{tabular}{|c|c|c|c|c|}
\hline $\begin{array}{c}\text { Laopodis } \\
(2008)\end{array}$ & $\begin{array}{l}\text { Fiscal Policy, Monetary } \\
\text { Policy, and the Stock } \\
\text { Market in the USA from } \\
1960 \text { to } 2004\end{array}$ & $\begin{array}{l}\text { All Share Index, } \\
\text { Monetary Policy } \\
\text { Rate, Inflation }\end{array}$ & $\begin{array}{c}\text { Vector } \\
\text { Autoregression } \\
\text { (VAR) } \\
\text { framework }\end{array}$ & $\begin{array}{l}\text { Negative response of the stock } \\
\text { market to innovations in inflation a } \\
\text { result is taken to suggest that the } \\
\text { stock market pays attention to } \\
\text { inflation information before pricing } \\
\text { assets }\end{array}$ \\
\hline
\end{tabular}

Source: Researchers Review of Studies on Government Policies, Stock Market Returns, and Performance

\section{Methodology}

The methodology of this study followed the Auto-regressive Distributive Lag (ARDL) procedure in estimating the models, whereas the granger causality test was employed in effect examination. The study covered a period of thirty-three (33) years from 1986 to 2018. We relied on the Nigeria Stock Exchange (NSE) and Central Bank of Nigeria (CBN) for the data employed in the analysis. We measured stock market development using three indices (stock market capitalization ratio, the value of stock traded ratio, and turnover ratio) based on World Bank (2013) global proxy for measuring the depth of stock market development. That notwithstanding, we also added the all-share index to capture how the market has performed over the period studied. We used fiscal deficit and total government expenditure to appraise fiscal policy.

In an attempt to examine the effect of fiscal policy on stock market development, the model of Ogbulu Torbira and Umezinwa (2015) was adapted. The original model is stated thus:

$A S I=f(P E X, D B T, N O R, M S P)$

Where:

ASI: All Share Index

PEX: Total Public Expenditure

DBT: Domestic Debt Outstanding

NOR: Non-Oil Revenue

MSP: Broad Money Supply

The model for this study based on the broad objective is stated as follows:

$S M D=f(F P)$

Where:

$S M D$ : Stock Market Development

FP: Fiscal Policy

The model of Ogbulu Torbira and Umezinwa (2015) was modified by removing domestic debt outstanding, non-oil revenue, and broad money supply, while fiscal deficit and government total expenditure were included. In this regard, the modified models of this study are stated as:

$A S I=f(F D)$

$M K T R=f(G T E X P)$

$V S T R=f(G T E X P)$

$T U R N=f(G T E X P)$

By econometrical transformation, equ. 2, 3, 4, and 5 are thus stated as:

$\operatorname{LogASI}_{t}=\beta_{0}+\beta_{1} \operatorname{LogFD}_{t}+u_{t}$

$\operatorname{LogMKTR}_{t}=\beta_{0}+\beta_{1} \operatorname{LogGTEXP} P_{t}+u_{t}$

$\operatorname{LogVSTR}_{t}=\beta_{0}+\beta_{1} \operatorname{LogGTEX} P_{t}+u_{t}$ 
$\operatorname{LogTURN}_{t}=\beta_{0}+\beta_{1} \log G T E X P_{t}+u_{t}$

The ARDL short-run estimates are depicted in equ. 11, 12, 13, and 14 .

$A S I_{t}=a_{0}+\sum_{i=1}^{p} a_{1 i} A S I_{t-i}+\sum_{i=1}^{q} a_{2 i} F D_{t-i}+\alpha E C M_{t-i}+u_{t}$
$M K T R_{t}=a_{0}+\sum_{i=1}^{q} a_{1 i} \operatorname{MKTR}_{t-i}+\sum_{i=1}^{q} a_{2 i} \operatorname{GTEXP}_{t-i}+\alpha E C M_{t-i}+u_{t}$

$\operatorname{VSTR}_{t}=a_{0}+\sum_{\substack{i=1 \\ p}}^{p} a_{1 i} \operatorname{VSTR}_{t-i}+\sum_{i=1}^{q} a_{2 i} G T E X P_{t-i}+\alpha E C M_{t-i}+u_{t}$

$\operatorname{TURN}_{t}=a_{0}+\sum_{i=1}^{p} a_{1 i} \operatorname{TURN}_{t-i}+\sum_{i=1}^{q} a_{2 i} \operatorname{GTEXP}_{t-i}+\alpha \operatorname{ECM}_{t-i}+u_{t}$

The ARDL long-run equation is shown in Equ. 15, 16, 17, and 18.

$A S I_{t}=a_{0}+\sum_{i=1}^{p} a_{1 i} A S I_{t-i}+\sum_{i=0}^{q_{1}} a_{2 i} F D_{t-i}+u_{t}$

$M K T R_{t}=a_{0}+\sum_{i=1}^{p} a_{1 i} M K T R_{t-i}+\sum_{i=0}^{q_{1}} a_{2 i} G T E X P_{t-i}+u_{t}$

$\operatorname{VSTR}_{t}=a_{0}+\sum_{i=1}^{p} a_{1 i} \operatorname{VSTR}_{t-i}+\sum_{i=0}^{q_{1}} a_{2 i} \operatorname{GTEXP}_{t-i}+u_{t}$

$\operatorname{TURN}_{t}=a_{0}+\sum_{i=1}^{p} a_{1 i} \operatorname{TURN}_{t-i}+\sum_{i=0}^{q_{1}} a_{2 i} \operatorname{GTEXP}_{t-i}+u_{t}$

Where:

ASI: All Share Index

MKTR: Market Capitalization Ratio

VSTR: Value of Stock Traded Ratio

TURN: Turnover Ratio

GTEXP: Government Total Expenditure

$\beta_{0}$ : constant coefficient

$u$ : Random error term and

$t$ : Time trend; normally included in standard time-series specifications to account for the omitted variables in the model.

In the ADF generally, evaluation of the existence or otherwise of unit root for the time series data follows equation as:

$\Delta Y_{t-1}=\alpha_{0}+\alpha_{2} Y_{t-1}+\sum_{i=1}^{\rho} \delta_{1} \Delta \mathrm{Y}_{\mathrm{t}-1}+\epsilon_{\mathrm{i}}$

Where: $Y_{t}=$ variable of choice; $\quad \alpha_{0}=$ intercept; $\quad \Delta=$ first difference operator; $\alpha_{1}=($ for $\mathrm{i}=1$ and 2 ) and $\delta_{i}$ (for $\mathrm{i}=1,2 \ldots \mathrm{Q}$ ) are constant parameters; $\sum_{i}=$ stationary stochastic process; $\mathrm{Q}=$ number of lagged terms chosen by Akaike Information Criterion (AIC) to ensure that $\sum_{i}$ is white 
noise. To test for the existence or otherwise of unit root, the following implied hypotheses are stated:

$\mathrm{H}_{0}: \alpha_{2}=0$, i.e. there is a unit root - implying time series is not stationary

$\mathrm{H}_{1}: \alpha_{2} \neq 0$, i.e. there is no unit root - implying the time series is stationary

From the econometric point of view, Phillips-Perron tests assess the null hypothesis of a unit root in a univariate time series $Y$ and tests use the model:

$\Delta Y_{t}=c+\delta \mathrm{t}+a Y_{t-1}+e(t)$

The null hypothesis restricts $a=1$. Variants of the test, appropriate for series with different growth characteristics, restrict the drift and deterministic trend coefficients, $c$ and, $\delta$ respectively, to be 0 . The tests use modified Dickey-Fuller statistics to account for serial correlations in the innovations process $e(t)$.

\section{Results and Discussion}

The descriptive statistics in Table 2 give an insight into the mean, standard deviation, minimum and maximum values, and the number of observations. All share index, market capitalization ratio, the value of the stock traded ratio, turnover ratio, fiscal deficit, and government total expenditure have the mean of 16606.63, 12.27848, 668.8455, 6.304242, -377908.3 and 2115898 respectively. The maximum and minimum value for all share index are 57990.22 and 163.8000, 56.0000 and 0.010000 for market capitalization ratio, 21904.30 and 0.450000 for the value of stock traded ratio, 17.56000 and 1.020000 for turnover ratio, 1170000 and -2208220 for fiscal deficit, and 7813740 and 16220.00 for government total expenditure. The standard deviation were observed to be 14969.90, 14.17410, 3812.143, 3.619724, 648174.3, and 2279937 sequentially for all share index, market capitalization ratio, the value of the stock traded ratio, turnover ratio, fiscal deficit, and government total expenditure.

\section{Table 2: Descriptive Statistics of Data}

\begin{tabular}{|cccccc|}
\hline & Mean & Std. Dev. & Min. & Max. & Obs. \\
\hline Panel A: Fiscal Policy & & & & & \\
\hline FD & -377908.3 & 648174.3 & -2208220 & 1170000 & 33 \\
\hline GTEXP & 2115898 & 2279937 & 16220.00 & 7813740 & 33 \\
\hline Panel B: Stock Market Development & & & & & \\
\hline ASI & 16606.63 & 14969.90 & 163.8000 & 57990.22 & 33 \\
\hline MKTR & 12.27848 & 14.17410 & 0.010000 & 56.00000 & 33 \\
\hline VSTR & 668.8455 & 3812.143 & 0.450000 & 21904.30 & 33 \\
\hline TURN & 6.304242 & 3.619724 & 1.020000 & 17.56000 & 33 \\
\hline
\end{tabular}

Source: E-views 10.0 Output Information

Data are expected to be stationary for inference made from estimation to be robust and statistically reliable. Most time-series data are encumbered by stationarity defect which leads to spurious regression result. To avoid this and ensure that the data are cleaned of the stationarity problem, this study applied the Augmented Dickey-Fuller (ADF) Test and Phillips Perron (PP) tests of unit root to determine the stationarity of the data. Tests for unit root was in level and first difference, and included in the test equation were: intercept, trend and intercept, and none. 
From the unit test result in Tables 4 and 6, the data were all stationary at first difference as against non-stationarity for all data in Tables 3 and 5.

Table 3: ADF Test Result at Level

\begin{tabular}{|ccccc|}
\hline Variables & Intercept & Trend and Intercept & None & Remark \\
\hline SMR & $-1.553027(0.49)$ & $-3.037810(0.14)$ & $-0.508671(0.49)$ & Not Stationary \\
\hline MKTR & $-1.540091(0.50)$ & $-2.092581(0.53)$ & $-0.826149(0.35)$ & Not Stationary \\
\hline VSTR & $-0.663787(0.84)$ & $-0.620935(0.97)$ & $0.117083(0.71)$ & Not Stationary \\
\hline TURN & $-2.566810(0.11)$ & $-3.021641(0.14)$ & $-1.295393(0.18)$ & Not Stationary \\
\hline FD & $-2.974389(0.50)^{* *}$ & $-4.123355(0.020)^{* *}$ & $-2.625967(0.01)^{*}$ & Stationary \\
\hline GTEXP & $3.642244(1.00)$ & $0.223285(0.99)$ & $3.640696(0.99)$ & Not Stationary \\
\hline
\end{tabular}

Source: E-views 10.0 Output Information

Note: p-values are in parentheses where $\left(^{*}\right)$ and $\left({ }^{* *}\right)$ denote significance at $1 \%$ and $5 \%$ respectively.

Table 4: ADF Test Result at First Difference

\begin{tabular}{|ccccc|}
\hline Variables & Intercept & Trend and Intercept & None & Remark \\
\hline SMR & $-5.608914(0.00)^{*}$ & $-5.513022(0.00)^{*}$ & $-5.827574(0.00)^{*}$ & Stationary \\
\hline MKTR & $-5.987502(0.00)^{*}$ & $-5.889935(0.00)^{*}$ & $-6.033705(0.00)^{*}$ & Stationary \\
\hline VSTR & $-5.011311(0.00)^{*}$ & $-5.153958(0.00)^{*}$ & $-5.008071(0.00)^{*}$ & Stationary \\
\hline TURN & $-7.794818(0.00)^{*}$ & $-3.843817(0.03)^{* *}$ & $-7.929573(0.00)^{*}$ & Stationary \\
\hline FD & $-4.706730(0.00)^{*}$ & $-4.658367(0.00)^{*}$ & $-4.391743(0.00)^{*}$ & Stationary \\
\hline GTEXP & $-5.863681(0.00)^{*}$ & $-4.932384(0.02)^{* *}$ & $-5.367073(0.00)^{*}$ & Stationary \\
\hline
\end{tabular}

Source: E-views 10.0 Output Information

Note: p-values are in parentheses where $\left(^{*}\right)$ and $\left(^{* *}\right)$ denote significance at $1 \%$ and $5 \%$ respectively.

Table 5: PP Test Result at Level

\begin{tabular}{|ccccc|}
\hline Variables & Intercept & Trend and Intercept & None & Remark \\
\hline SMR & $-1.409445(0.56)$ & $-3.137535(0.12)$ & $-0.239724(0.59)$ & Not Stationary \\
\hline MKTR & $-1.538211(0.50)$ & $-2.220717(0.46)$ & $-0.794372(0.36)$ & Not Stationary \\
\hline VSTR & $11.56173(1.00)$ & $14.57693(1.00)$ & $0.117083(0.71)$ & Not Stationary \\
\hline TURN & $-2.455017(0.14)$ & $-2.962085(0.16)$ & $-1.054596(0.25)$ & Not Stationary \\
\hline FD & $-2.090049(0.25)$ & $-0.898918(0.94)$ & $-1.986938(0.05)^{* *}$ & Stationary \\
\hline GTEXP & $3.360830(1.00)$ & $0.117023(0.99)$ & $5.036094(1.00)$ & Not Stationary \\
\hline
\end{tabular}

Source: E-views 10.0 Output Information

Note: p-values are in parentheses where $\left(^{*}\right)$ and $\left(^{* *}\right)$ denote significance at $1 \%$ and $5 \%$ respectively.

Table 6: PP Test Result at First Difference

\begin{tabular}{|ccccc|}
\hline Variables & Intercept & Trend and Intercept & None & Remark \\
\hline SMR & $-7.231278(0.00)^{*}$ & $-7.081702(0.00)^{*}$ & $-6.366274(0.00)^{*}$ & Stationary \\
\hline MKTR & $-6.024561(0.00)^{*}$ & $-5.922322(0.00)^{*}$ & $-6.068685(0.00)^{*}$ & Stationary \\
\hline VSTR & $-5.011311(0.00)^{*}$ & $-5.153958(0.00)^{*}$ & $-5.008071(0.00)^{*}$ & Stationary \\
\hline TURN & $-9.900898(0.00)^{*}$ & $-10.80167(0.00)^{*}$ & $-10.08779(0.00)^{*}$ & Stationary \\
\hline FD & $-5.245316(0.00)^{*}$ & $-5.093185(0.00)^{*}$ & $-5.293398(0.00)^{*}$ & Stationary \\
\hline GTEXP & $-4.124131(0.00)^{*}$ & $-5.479704(0.00)^{*}$ & $-2.810737(0.00)^{*}$ & Stationary \\
\hline
\end{tabular}

Source: E-views 10.0 Output Information

Note: $p$-values are in parentheses where $\left(^{*}\right)$ and $(* *)$ denote significance at $1 \%$ and $5 \%$ respectively.

The ARDL test of the long-run relationship between government expenditure and selected macroeconomic variables are detailed in Tables $7-10$. From the result of the ARDL long-run relationship, it was clear that there is no long-run relationship between fiscal policy (fiscal 
deficit and government total expenditure) and stock market development (all-share index, market capitalization ratio, the value of stock traded ratio, and turnover ratio) in Nigeria. The fstatistic of $1.054522,0.967690,0.604652$ and 3.103089 respectively for model one (Table 7), two (Table 8), three (Table 9), and four (Table 10) are less than the lower and upper bound test of 3.62 and 4.16 at $5 \%$ level of significance.

Table 7: Bound Test for All-Share Index and Fiscal Deficit

\begin{tabular}{|cccc|}
\hline T-Test & \multicolumn{2}{c|}{$5 \%$ Critical Value Bound } & Remark \\
\hline F-Statistic & Lower Bound & Upper Bound & \\
\hline 1.054522 & 3.62 & 4.16 & Null Hypothesis Accepted \\
\hline
\end{tabular}

Source: E-views 10.0 Output Information

Table 8: Bound Test for Market Capitalization Ratio and Government Total Expenditure

\begin{tabular}{|cccc|}
\hline T-Test & \multicolumn{2}{c|}{$5 \%$ Critical Value Bound } & Remark \\
\hline F-Statistic & Lower Bound & Upper Bound & \\
\hline 0.967690 & 3.62 & 4.16 & Null Hypothesis Rejected \\
\hline
\end{tabular}

Source: E-views 10.0 Output Information

Table 9: Bound Test for Value of Stock Traded Ratio and Government Total Expenditure

\begin{tabular}{|cccc|}
\hline T-Test & \multicolumn{2}{c|}{$5 \%$ Critical Value Bound } & Remark \\
\hline F-Statistic & Lower Bound & Upper Bound & \\
\hline 0.604652 & 3.62 & 4.16 & Null Hypothesis Rejected \\
\hline
\end{tabular}

Source: E-views 10.0 Output Information

Table 10: Bound Test for Turnover Ratio and Government Total Expenditure

\begin{tabular}{|cccc|}
\hline T-Test & \multicolumn{4}{c|}{$5 \%$ Critical Value Bound } & Remark \\
\hline F-Statistic & Lower Bound & Upper Bound & \\
\hline 3.103089 & 3.62 & 4.16 & Null Hypothesis Accepted \\
\hline
\end{tabular}

Source: E-views 10.0 Output Information

The relationship in the short run between stock market development and fiscal policy was appraised by the ARDL estimation. Table 11 provides evidence of a negative relationship between all share index and fiscal deficit. A unit rise in fiscal deficit leads to 0.5798 factor depreciation in all-share index. When the fiscal deficit is held constant, all share index would worth 3159.99. For the adjusted R-square, fiscal deficit significantly explained $72.15 \%$ changes in all-share index (f-statistic p-value of 0.00 is significant at $5 \%$ level of significance). From the Durbin Watson value of 1.95, there is no issue of autocorrelation in the model.

Table 11: ARDL Regression Result of All-Share Index and Fiscal Deficit

\begin{tabular}{|ccc|}
\hline Variables & Coefficient & Prob. \\
\hline ASI(-1) & 0.833260 & 0.0000 \\
\hline FD & -0.001307 & 0.5798 \\
\hline C & 3159.986 & 0.1401 \\
\hline Adjusted R-squared & 0.721462 & \\
\hline F-statistic & 41.14769 & \\
\hline Prob(F-statistic) & 0.000000 & \\
\hline Durbin-Watson stat & 1.957869 & \\
\hline
\end{tabular}

Source: E-views 10.0 Output Information

The regression output in Table 12 provides evidence that government total expenditure has an insignificant positive relationship with the market capitalization ratio. The market capitalization ratio would be valued at $1.95 \%$ assuming government total expenditure is held 
constant. Percentage rise in government total expenditure implies a rise in market capitalization ratio by a factor of 4.47 . There is no problem with autocorrelation in the model as depicted by the Durbin Watson value of 2.0. Looking at the value of the adjusted R-squared, 73.27\% variation in market capitalization ratio was accounted for by government total expenditure which is significant as revealed by the f-statistic (43.49) and p-value (0.00).

Table 12: ARDL Regression Result of Market Capitalization Ratio and Government Total Expenditure

\begin{tabular}{|ccc|}
\hline Variables & Coefficient & Prob. \\
\hline MKTR(-1) & 0.811291 & 0.0000 \\
\hline GTEXP & $4.47 \mathrm{E}-07$ & 0.5727 \\
\hline C & 1.951011 & 0.2989 \\
\hline Adjusted R-squared & 0.732726 & \\
\hline F-statistic & 43.49288 & \\
\hline Prob(F-statistic) & 0.000000 & \\
\hline Durbin-Watson stat & 2.006417 & \\
\hline
\end{tabular}

Source: E-views 10.0 Output Information

In Table 13, government total expenditure is positively and significantly related to the value of the stock traded ratio. The value of the stock traded ratio would down by 874.9 if the government total expenditure is kept constant. Percentage rise in government total expenditure leads to $0.47 \%$ appreciation in the value of the stock traded ratio. About $24.32 \%$ of changes in the value of the stock traded ratio were attributed to fluctuation in government total expenditure. Government total expenditure significantly explained the changes in the value of the stock traded ratio as shown by the f-statistic (4.32) and p-value (0.01). From the coefficient of the Durbin Watson, there is no element of autocorrelation in the model as the Durbin Watson coefficient of 1.42 is still within the acceptable range of no autocorrelation in a model.

Table 13: ARDL Regression Result of Value of Stock Traded Ratio Government Total Expenditure

\begin{tabular}{|ccc|}
\hline Variables & Coefficient & Prob. \\
\hline VSTR(-1) & -28.18014 & 0.7712 \\
\hline GTEXP & 0.004778 & 0.0171 \\
\hline GTEXP(-1) & -0.004495 & 0.0395 \\
\hline C & -874.9049 & 0.4069 \\
\hline Adjusted R-squared & 0.243272 & \\
\hline F-statistic & 4.321950 & \\
\hline Prob(F-statistic) & 0.012644 & \\
\hline Durbin-Watson stat & 1.427472 & \\
\hline
\end{tabular}

Source: E-views 10.0 Output Information

Table 14 provides evidence of a positive relationship between turnover ratio and government total expenditure. A unit rise in government total expenditure leads to 2.99 factor increase in the turnover ratio. When government total expenditure is held constant, turnover ratio would worth 1.743. For the adjusted R-square, government total expenditure significantly explained $43.01 \%$ changes in turnover ratio ( $\mathrm{f}$-statistic p-value of 0.00 is significant at a $5 \%$ level of significance). From the Durbin Watson value of 2.00, there is no issue of autocorrelation in the model. 


\section{Table 14: ARDL Regression Result of Turnover Ratio Government Total Expenditure}

\begin{tabular}{|ccc|}
\hline Variables & Coefficient & Prob. \\
\hline TURN(-1) & 0.641160 & 0.0002 \\
\hline GTEXP & $2.99 \mathrm{E}-06$ & 0.0670 \\
\hline GTEXP(-1) & $-3.12 \mathrm{E}-06$ & 0.0854 \\
\hline C & 1.743070 & 0.0974 \\
\hline Adjusted R-squared & 0.430127 & \\
\hline F-statistic & 8.799376 & \\
\hline Prob(F-statistic) & 0.000286 & \\
\hline Durbin-Watson stat & 2.001133 & \\
\hline
\end{tabular}

Source: E-views 10.0 Output Information

The residual diagnostics visa viz: serial correlation and heteroskedasticity in Tables 15 and 16 absolve the models estimated of serial correlation and heteroskedasticity problems ( $\mathrm{p}$-values > 0.05). The residual diagnostic in Table 17 provided evidence that the models were well-specified and no misspecification issue was observed ( $\mathrm{p}$-value $>0.05$ ).

Table 15: Serial Correlation LM Test

\begin{tabular}{|cccc|}
\hline Estimated Regression Equations & Obs*R-squared & F-statistic & P-value \\
\hline ASI $\rightarrow$ FD & 3.570220 & 1.695334 & 0.2025 \\
\hline MKTR $\rightarrow$ GTEXP & 0.204969 & 0.087029 & 0.9169 \\
\hline VSTR $\rightarrow$ GTEXP & 2.617488 & 1.158082 & 0.3298 \\
\hline TURN $\rightarrow$ GTEXP & 0.080931 & 0.032962 & 0.9676 \\
\hline
\end{tabular}

Source: E-views 10.0 Output Information

Table 16: Heteroskedasticity Test

\begin{tabular}{|cccc|}
\hline Estimated Regression Equations & Obs*R-squared $^{*}$ & F-statistic & P-value \\
\hline ASI $\rightarrow$ FD & 2.777992 & 1.457612 & 0.1158 \\
\hline MKTR $\rightarrow$ GTEXP & 5.353904 & 2.913433 & 0.0703 \\
\hline VSTR $\rightarrow$ GTEXP & 1.859061 & 1.390501 & 0.0675 \\
\hline TURN $\rightarrow$ GTEXP & 4.062183 & 1.357075 & 0.2762 \\
\hline
\end{tabular}

Source: E-views 10.0 Output Information

Table 9: Ramsey Reset Specification

\begin{tabular}{|cccc|}
\hline Estimated Regression Equations & F-statistic & $\mathrm{df}$ & P-value \\
\hline $\mathrm{ASI} \rightarrow$ FD & 0.823212 & $(7,22)$ & 0.1294 \\
\hline MKTR $\rightarrow$ GTEXP & 0.059404 & $(7,22)$ & 0.2002 \\
\hline VSTR $\rightarrow$ GTEXP & 0.880894 & $(1,27)$ & 0.0752 \\
\hline TURN $\rightarrow$ GTEXP & 2.828278 & $(1,27)$ & 0.1042 \\
\hline
\end{tabular}

Source: E-views 10.0 Output Information

The effect of fiscal policy on stock market development was ascertained using the granger causality test. Evidence abound from Table 18 is that there is a no unidirectional causal relationship running from fiscal deficit to all share index; government total expenditure to market capitalization ratio; and government total expenditure to turnover ratio at a $5 \%$ significance level. The result implies that fiscal deficit and government total expenditure have no significant effect on all share index, market capitalization ratio, and turnover ratio in Nigeria. That notwithstanding, there was evidence of unidirectional causal relationship flowing from government total expenditure to value of stock traded ratio at a significance level of $5 \%$. In 
essence, government total expenditure exerts a significant influence on the value of the stock traded ratio.

Table 18: Granger Causality Analysis

\begin{tabular}{|c|c|c|c|c|}
\hline Null Hypothesis: & Obs & F-Statistic & Prob. & Remarks \\
\hline FD does not Granger Cause ASI & 32 & 1.63186 & 0.2116 & No Causality \\
\hline ASI does not Granger Cause FD & & 0.39436 & 0.5349 & No Causality \\
\hline GTEXP does not Granger Cause MKTR & 32 & 0.20157 & 0.6568 & No Causality \\
\hline MKTR does not Granger Cause GTEXP & & 1.93571 & 0.1747 & No Causality \\
\hline GTEXP does not Granger Cause VSTR & 32 & 5.01501 & 0.0330 & Causality \\
\hline VSTR does not Granger Cause GTEXP & & 0.02955 & 0.8647 & No Causality \\
\hline GTEXP does not Granger Cause TURN & 32 & 0.40385 & 0.5301 & No Causality \\
\hline TURN does not Granger Cause GTEXP & & 0.65297 & 0.4256 & No Causality \\
\hline
\end{tabular}

Source: E-views 10.0 Output Information

The ARDL long-run relationship in Tables $7-10$ reveals that there is no long-run relationship between fiscal policy and stock market development in Nigeria. This would be attributed to the under-develop nature of the capital market as well as the fragmented nature of the financial system. Nigeria is seen as a bank-based economy because finance for productive economic activities are majorly sourced from the banking system. Only a few high corporate firms are quoted and traded on the floor of the Nigerian Stock Exchange (NSE). From the ARDL result in Tables 11 - 13, government total expenditure was found to be positively related to stock market development indices (market capitalization ratio, the value of stock traded ratio, and turnover ratio) in line with a priori expectation of a positive linkage. This supports the works of Perveen and Rahman (2018), Onyema (2017), Ali, Zaman, Ziaei, and Anuar (2014) but disagreed with of Ogbulu, Torbira, and Umezinwa (2015), Hsing (2013) and Anghelache, Jakova, and Oanea (2016) on the negative association between government expenditure and development in the stock market. Conventionally, when the government increases its recurrent spending, there would be more funds in the hands of the citizen. This would trigger more investment in the stock market which in turn would increase share prices, hence increased returns reflected by changes in the all-share index.

The fiscal deficit in Table 14 has a negative relationship with all share indexes in Nigeria in line with a priori expectation. In the neoclassical point of view, fiscal deficit crowds out private investment. When investments are not made by individuals and corporate organizations, returns on quoted securities would depreciate resulting in loss of earnings from financial assets. In terms of the effect on fiscal policy on stock market development, the granger causality analysis in Table 18 provided evidence that it is only government expenditure that has a significant effect on the value of the stock ratio. Fiscal deficit in terms of government total expenditure and the fiscal deficit has no significant effect on all share index, market capitalization, and turnover ratio in Nigeria. This is in affirmation with the study of Kuncoro (2017) that fiscal policy does not magnificently influence activities in the stock exchange but would not validate the findings of Eyo (2018) and Mutulis and Olweny (2018). 


\section{Conclusion and Policy Implication}

This article presents a study on the effect of fiscal policy on stock market development in an emerging economy in West Africa: Nigeria from 1986 to 2018. Specifically, we evaluated the effect of fiscal deficit on all share indexes; government total expenditure on market capitalization ratio, the value of stock traded, and turnover ratio using data from the Central Bank of Nigeria (CBN) and Nigerian Stock Exchange (NSE). With the application of the granger causality test, government total expenditure has a significant effect on the value of stock traded. Similarly, fiscal deficit has no significant effect on all share index; government expenditure has no significant effect on market capitalization ratio and turnover ratio. To this end, this study concludes that stock market development in Nigeria is not magnificently affected by a fiscal policy defined in terms of fiscal deficit and government total expenditure. The government should implement its fiscal policies to carefully accommodate the development of the stock market, as changes in fiscal policy would affect activities in the market and ultimately the economy in general. Efficient operation of the stock market would enable firms' access to longterm capital and reduce reliance on the banking sector which are characterized by short to medium-term finance.

Acknowledgement: We appreciate and acknowledge the contribution of the anonymous reviewers who helped us to improve the manuscript by their valuable comments.

Author Contributions: This study was conceptualized by Dr. Paschal Chikwado Nwakobi and he also wrote the first draft of the manuscript. Amalachukwu Chijindu Ananwude sourced the data, performed the analysis and interpreted the results. Chinedu Maurice Umezurike reviewed the first draft of the manuscript and managed relevant literature.

Conflict of Interest: The authors declare no conflict of interest.

\section{REFERENCES}

Afroze, R. (2013). Impact of monetary policy of Bangladesh bank on the performance of stock market in Bangladesh. ASA University Review, 7(1), 1-11. Retrieved from http://www.asaub.edu.bd/data/asaubreview/v7n1sl1.pdf

Akanni, K. A., \& Osinowo, O. H. (2013). Effect of fiscal instability on economic growth in Nigeria. Advances in Economics and Business, 1(2), 124-133. http://dx.doi.org/10.13189/aeb.2013.010207

Ali, G., Zaman, K., Ziaei, S. M., \& Anuar, M. M. (2014). Stock return response to monetary and fiscal policy interaction in Singapore. Mediterranean Journal of Social Sciences, 5(27), 1712-1727. http://dx.doi.org/10.5901/mjss.2014.v5n27p1712

Anghelache, G. V., Jakova, S., \& Oanea, D. C. (2016). Fiscal policy and capital market performance: Evidence from EU countries from Central and Eastern Europe. International Journal of Academic Research in Accounting, Finance and Management Sciences, 6(2), 34-43. Retrieved from https://ideas.repec.org/a/hur/ijaraf/v6y2016i2p34-43.html

Atgur, M., \& Yigit, F. (2017). Causality analysis of the impact of monetary policy on stock markets: The case of Turkey 2006-2016. Journal of Knowledge Management, Economics and Information Technology, 7(4), 1-20. Retrieved from https://www.scientificpapers.org/volume-7-2017/volume-7-issue-no-4/causality-analysis-ofthe-impact-of-monetary-policy-on-stock-markets-the-case-of-turkey/ 
Bekhet, H. I., \& Othman, S. N. (2013). Examining the role of fiscal policy in Malaysian stock market. International Business Research, 5(12), 59-67. http://dx.doi.org/10.5539/ibr.v5n12p59

Chen, X., \& Xie, X. (2016). How responsive is China's stock market to the monetary Policies (Conference Paper). International Multi Conference of Engineers and Computer Scientists, March 16 - 18. Retrieved from https://www.google.com/url?sa=t\&rct=j\&q=\&esrc=s\&source=web\&cd=\&cad=rja\&uact=8\&ved=2ahUKEwip nH5zpXsAhWIT8AKHfqbCqcQFjAAegQIBRAC\&url=http\%3A\%2F\%2Fwww.iaeng.org\%2Fpublication\%2F IMECS2016\%2FIMECS2016_pp788-793.pdf\&usg=AOvVaw01jbkvxvVFw2yOJmFTURxz

Cheng, C., \& Sun, M. (2013). A financial crisis study: how fiscal and monetary policy affect the stock market returns considering the specific counties (Master's thesis, Ekonomihogskolan Lund University). Retrieved from https://www.google.com/url?sa=t\&rct=j\&q=\&esrc=s\&source=web\&cd=\&cad=rja\&uact=8\&ved=2ahUKEwjw mbq2z5XsAhUSXMAKHdHKDeYQFjAAegQIAhAC\&url=https\%3A\%2F\%2Fcore.ac.uk\%2Fdownload\%2F pdf\%2F289953613.pdf\&usg=AOvVaw2IZkjp3uUQ6FPTcC-E14j2

Echekoba, F. N., Okaro, C. S., Ananwude, A. C., \& Akuesodo, O. E. (2017). Monetary policy and capital market performance: An empirical evidence from Nigerian data. Research Journal of Economics, 2(1), 1-6. Retrieved from: https://www.scitechnol.com/peer-review/monetary-policy-and-capital-market-performance-anempirical-evidence-from-nigerian-data-ybBp.php?article_id=7204

Echekoba, F. N., Ananwude, A. C., \& Oyinloye, L. (2018). Effect of monetary policy on the performance of the Nigerian capital market (1986 - 2016): Stylized facts from ARDL approach. Advances in Research, 14(6), 1-15. http://dx.doi.org/10.9734/AIR/2018/37989

Eyo, E. (2018). Impact of fiscal policy on the performance of the Nigerian stock exchange (1980-2012). International Journal of Interdisciplinary Social Science Studies, 2(1), 36-44. Retrieved from https://www.researchgate.net/publication/326271639_IMPACT_OF_FISCAL_POLICY_ON_THE_PERFOR MANCE_OF_THE_NIGERIAN_STOCK_EXCHANGE_1980-2012

Favero, C., \& Giavazzi, F. (2007). Debt and the effects of fiscal policy (Working Paper Series No. 07-4). Federal Reserve Bank of USA. Retrieved from https://www.bostonfed.org/publications/research-department-workingpaper/2007/debt-and-the-effects-of-fiscal-policy.aspx

Geraldo, E. Y. (2011). Fiscal policy, monetary policy and stock market activity in Ghana (Master's Thesis, Kwame Nkrumah University of Science and Technology, Ghana). Retrieved from https://www.google.com/url?sa=t\&rct=j\&q=\&esrc=s\&source=web\&cd=\&cad=rja\&uact=8\&ved=2ahUKEwjGi cb30ZXsAhWeSEEAHTslBOcQFjABegQIBRAC\&url=http\%3A\%2F\%2Fir.knust.edu.gh\%2Fbitstream\%2F12 3456789\%2F4201\%2F1\%2FErnest\%2520thesis.pdf\&usg=AOvVaw3zsJNEgkcdo8vFDQQguDat

Gowriah, S., Seetanah, B., John, L. M., \& Keshav, S. (2014). The effects of monetary and fiscal policies on the stock exchange: Evidence from an island economy. Business \& Management Review, 4(4), 321-332. Retrieved from https://www.google.com/url?sa=t\&rct=j\&q=\&esrc=s\&source=web\&cd=\&cad=rja\&uact=8\&ved=2ahUKEwiJr 5qT0pXsAhURHcAKHWUGDugQFjAAegQIARAC\&url=https\%3A\%2F\%2Fpdfs.semanticscholar.org\%2F5 f88\%2F476d8229d3cff1025479b1a8306f3d9c9c21.pdf\&usg=AOvVaw1WfdTqNKTlQ3WA0RS5Reff

Handoyo, R. W., Jusoh, M., \& Zaidi, A. S. (2015). Impact of monetary policy and fiscal policy on Indonesian stock market. Expert Journal of Economics, 3(2), 113-126. Retrieved from https://www.google.com/url?sa=t\&rct=j\&q=\&esrc=s\&source=web\&cd=\&cad=rja\&uact=8\&ved=2ahUKEwiF 26a50pXsAhX1QUEAHXn4C-

kQFjAAegQIBRAC\&url=http\%3A\%2F\%2Feconomics.expertjournals.com\%2Fark\%3A\%2F16759\%2FEJE_31 2handoyo113-126.pdf\&usg=AOvVaw37JTZA6VGfsOShxgp5ehcc

Hsing, Y. (2013). Effects of fiscal policy and monetary policy on the stock market in Poland. Economiee, 1, 19-25. Retrieved from https://www.google.com/url?sa=t\&rct=j\&q=\&esrc=s\&source=web\&cd=\&cad=rja\&uact=8\&ved=2ahUKEwiK 67zR0pXsAhWkoFwKHbsaDOQQFjAJegQIBhAC\&url=http\%3A\%2F\%2Fwww.mdpi.com\%2F22277099\%2F1\%2F3\%2F19\%2Fpdf\&usg=AOvVaw03M4XSyEzutviISjYryy 
Iglesias, E. M., \& Haughton, A. Y. (2011). Interaction between monetary policy and stock prices: A comparison between the Caribbean and the US. Retrieved from https:/www.google.com/url?sa=t\&rct=j\&q=\&esrc=s\&source=web\&cd=\&cad=rja\&uact=8\&ved=2ahUKEwi29 qHs0pXsAhXVIFwKHWLQBOQQFjABegQIBRAC\&url=http\%3A\%2F\%2Fwww.econmodels.com\%2Fuploa d7282\%2F64bdf3c8cb663e4058c8892f37ceebdd.pdf\&usg=AOvVaw1vQ7pP8fny1iPL_q8e6tq3

Kuncoro, H. (2017). Fiscal policy and stock market returns volatility: the case of Indonesia. International Journal of Economic Policy in Emerging Economies, 10(2), 153-170. https://doi.org/10.1504/IJEPEE.2017.10006012

Laopodis, N. T. (2008). Fiscal policy and stock market efficiency: Evidence for the United States. The Quarterly Review of Economics and Finance, 49(2), 633-650. https://doi.org/10.1016/j.qref.2007.10.004

Mohamadpour, B., Behravan, N., Espahbodi, S., \& Karimi, R. (2012). An empirical study of relationship between monetary policy and stock market performance in Malaysia. Australian Journal of Basic and Applied Sciences, 6(12): 142-148. Retrieved from https://www.researchgate.net/publication/289750979_An_empirical_study_of_relationship_between_mone tary_policy_and_stock_market_performance_in_Malaysia

Muktadir-Al-Mukit, D., \& Shafiullah, A. Z. M. (2012). Impact of monetary policy on post crashed stock market performance: Evidence from Dhaka stock exchange. Journal of Business \& Economics, 4(1), 106-123. Retrieved from https://www.semanticscholar.org/paper/Impact-of-Monetary-Policy-on-Post-Crashed-StockMukit/07954bdbec5b1cef8a04b4b1cf26e63e74a43488?p2df

Muktadir-Al-Mukit, D. (2013). An econometric analysis of the impact of monetary policy on stock market performance in Bangladesh. World Review of Business Research, 3(3), 16 - 29. Retrieved from https://www.researchgate.net/publication/270450600_An_Econometric_Analysis_of_the_Impact_of_Monet ary_Policy_on_Stock_Market_Performance_in_Bangladesh

Mutulis, M. V., \& Olweny, T. (2018). The effect of fiscal policy on the performance of the Nairobi securities exchange in Kenya. International Journal of Economics, Commerce and Management, 6(6), 294-311. Retrieved from http://ijecm.co.uk/

Nemaorani, T. (2012). Impact of monetary policy on stock prices: Evidence from Botswana (Master's Thesis, University of Botswana, Botswana). https://www.google.com/url?sa=t\&rct=j\&q=\&esrc=s\&source=web\&cd=\&cad=rja\&uact=8\&ved=2ahUKEwivj YT1ZXsAhVNecAKHUbPBOwQFjABegQIARAC\&url=http\%3A\%2F\%2Feconsult.co.bw\%2Ftempex\%2FIm pact $\% 2520$ of $\% 2520$ monetary $\% 2520$ policy $\% 2520$ on $\% 2520$ stock $\% 2520$ prices $\% 2520$ Evidence $\% 2520$ from $\% 252$ 0Botswana.pdf\&usg=AOvVaw0vUcKvKExN0jRGXRZoql3a

Nwakoby, C. I. N., \& Alajekwu, U. B. (2016). Effect of monetary policy on Nigerian stock market performance. International Journal of scientific research and management, 4(9), 4530 - 4442. Retrieved from https://www.ijsrm.in/index.php/ijsrm/article/view/548

Nwaogwugwu, I. C. (2018). The effects of monetary and fiscal policy on the stock market in Nigeria. Journal of Economics and Development Studies, 6(1), 79-85. https://doi.org/10.15640/jeds.v6n1a8

Ogbulu, O. M., Torbira, L. L., \& Umezinwa, C. L. (2015). Assessment of the impact of fiscal policy operations on stock price performance: Empirical evidence from Nigeria. International Journal of Financial Research, 6(2), 190-202. https://doi.org/10.5430/ijfr.v6n2p190

Okonkwo, V. I., Ananwude, A. C., \& Echekoba, F. N. (2015). Nigeria stock market development and economic growth: A time series analysis (1993 - 2013). Scholars Journal of Economics, Business and Management, 2(3), 280-293. Retrieved from https://www.semanticscholar.org/paper/Nigeria-Stock-Market-Development-andEconomic-A-\%E2\%80\%93-Okonkwo-Ananwude/770c9f6a7418af6ba9ca22425dd63db2f8d131a6

Onyema, J. (2017). Stock market response to fiscal policy in Nigeria: Empirical evidence. International Journal in Management and Social Science, 5(12), 247-263. Retrieved from https://www.researchgate.net/publication/322976969_STOCK_MARKET_RESPONSE_TO_FISCAL_POLIC Y_IN_NIGERIA_EMPIRICAL_EVIDENCE

Osamwonyi, I. O., \& Evbayiro-Osagie, E. I. (2012). The relationship between macroeconomic variables and stock market index in Nigeria. Journal of Economics, 3(1), 55-63. https://doi.org/10.1080/09765239.2012.11884953 
Perveen, S., \& Rahman, M. (2018). Impact of fiscal and monetary policies on stock market performance: An empirical study of Pakistan stock exchange. Journal of Finance $\mathcal{E}$ Economics Research, 3(2), 2-23. Retrieved from https://ideas.repec.org/a/gei/jnlfer/v3y2018i2p2-23.html

Prukumpai, S. (2019). How does the Thai Stock Market respond to monetary and fiscal policy shocks? DLSU Business E Economics Review, 28(2), 52-68. Retrieved from https:/www.google.com/url?sa=t\&rct=j\&q=\&esrc=s\&source=web\&cd=\&cad=rja\&uact=8\&ved=2ahUKEwjM KLy2ZXsAhXbQEEAHbGWAeoQFjABegQIAhAC\&url=http\%3A\%2F\%2Fdlsu-ber.com\%2Fwpcontent $\% 2$ Fuploads $\% 2 F 2019 \% 2 F 02 \% 2 F 5$ PRUKUMPAI-revised 021319.pdf\&usg=AOvVaw3DG7eaBZPnyptXqL0p3gMg

Qayyum, A., \& Anwar, S. (2011). Impact of monetary policy on the volatility of stock market in Pakistan. Retrieved from https://mpra.ub.uni-muenchen.de/31188/.

Shrestha, P. K., \& Subedi, B. J. (2014). Determinants of stock market performance in Nepal. NRB Economic Review, 2, 26-40. $\quad$ Retrieved from https://www.google.com/url?sa=t\&rct=j\&q=\&esrc=s\&source=web\&cd=\&cad=rja\&uact=8\&ved=2ahUKEwjf0 7qa2pXsAhXQEcAKHaU0CYQFjABegQIBRAC\&url=https\%3A\%2F\%2Fideas.repec.org\%2Fa\%2Fnrb\%2Fjo urnl\%2Fv26y2014i2p25-40.html\&usg=AOvVaw0P_xl8buO8tU86Hw--Wx2d

Singh, A. (2014). A study of monetary policy impact on stock market returns. Indian Research Journal, 1(5), 1-12. Retrieved from www.indianresearchjournal.com

Wang, S., \& Mayes, D. G. (2012). Monetary policy announcements and stock reactions: An international comparison. The North American Journal of Economics and Finance, 23(2), 145-164. https://doi.org/10.1016/j.najef.2012.02.002

Word Bank (2013). Rethinking the role of the state in finance. Global financial development report. Retrieved from https://openknowledge.worldbank.org/bitstream/handle/10986/11848/Global\%20Financial\%20Developmen t\%20Report\%202013.pdf. 